\title{
Structural Work Duration Estimation and Analysis of Tower-Type Residential Construction Project
}

\author{
Seok Heon Yun and Sang Chul Kim \\ Department of Architectural Engineering, Engineering Research Institute, GyeongSang National University, Jinju, Korea \\ Department of Architectural Engineering, Hanbat National University, Daejeon, Korea
}

\begin{abstract}
In order to shorten construction duration in high-rise project, construction company tried to make various system method toward simplifying construction method and shortening construction duration. Though high-rise tower-type residential project are growing, there are few case study. Then, the data for preliminary schedule planning in high-rise tower-type residential project are rare. This purpose of research shows construction method in structural work in high-rise tower-type residential project, suggests schedule planning in structural work through case studies. The structural work in high-rise tower-type residential project was divided 1) completion of form in lower part and 2) the typical floor under penthouse. The statistical analysis were done in two parts, the data from analysis were used in simulation. Finally, researcher confirmed the difference between real construction duration and the figure from simulation. The results shows that the more construction duration is long, the less ACS's cost is low. It means the effectiveness is increasing in ACS, if the floor number is high.
\end{abstract}

Keywords: Form, Structural Work, Guide-rail System, Auto-climbing System, Simulation

\section{INTRODUCTION}

High-rise residential projects have been growing recently due to increased land price and enhanced life cycle, thus, the length of construction has increased. Likewise, the duration of proper construction and the baseline for the schedule are needed to ensure effective schedule management (Ji and Hyun, 2012). In order to shorten the duration of construction for high-rise projects, a construction company tried to introduce various system methods toward simplifying construction phases and shortening its duration (Han et al., 2004). Because tower-type residential projects are quite high and involve repeated processes, there is a need to minimize the cycle time per floor, such as TACT (Sim et al., 2009). Though highrise, tower-type residential projects are growing, there have been few case studies. Thus, the data for preliminary schedule planning in high-rise, tower-type residential projects are rare.

The purpose of this research is to show the construction methods in structural work involved in high-rise, tower-type residential

Corresponding Author : Sang-chul Kim, Assistant Professor Department of Architectural Engineering, Hanbat National University San 16-1 Dukmyung-dong, Yuseong-gu, Daejeon, South Korea, 305-719 Tel: +82 428211123 e-mail : harvard9@hanbat.ac.kr

This work was supported by NRF Research Fund (2011-001585) in 2012

This is an Open Access article distributed under the terms of the Creative Commons Attribution Non-Commercial License (http://creativecommons. org/licenses/by-nc/3.0/) which permits unrestricted non-commercial use, distribution, and reproduction in any medium, provided the original work is properly cited. projects, and to suggest schedule planning in structural work through case studies.

The research was performed as follows:

First, the structural work process of a residential project was analyzed, and the schedule planning of existing structural work was investigated.

In order to distinguish the existing structural work of a residential project, it was analyzed that the main construction methods in high-rise, tower-type residential projects were aimed at shortening construction time. Next, the construction methods were analyzed through a case study, wherein the difference between schedule planning and actual construction duration were investigated. Then, the research suggested the estimating method of construction duration in high-rise, tower-type residential projects.

The structural work in high-rise, tower-type residential projects was divided into: 1) completion of form in the lower part, and 2) the typical floor under the penthouse. The statistical analysis was done in two parts, with the data from the analysis used in simulation. Finally, the researcher confirmed the difference between the actual construction duration and the simulated figure. Because of variation in the design, the lower part of the residential project, the underground frame, and the penthouse were excluded in this research.

\section{THE SCHEDULE MECHANISM OF TYPICAL FLOOR STRUCTURAL WORK}

Concrete curing, form remaining period, and worker planning are major influences on construction duration (Bang et al., 2001). In order to define the logical influence to construction duration, the schedule mechanism for a typical floor formwork should be 
adopted. Then, in this chapter, activities are abstracted, while the relation between activities are defined to analyze the schedule mechanism for a typical floor formwork. Then, worker planning, concrete curing, and form remaining period are investigated. The activity duration is estimated, and the preliminary schedule is accomplished.

\subsection{WBS of structural work}

Structural work consists of formwork, rebar work, concrete work, mechanical work, and electronic/communication work. The activities under work item are shown in Table 1, and are divided into horizontal/vertical and construction phases. The dividing principle of an activity is as follows:

- If work item is different, the activity is separated.

- If work item is same and production unit are different, the activity is separated.

- Though work item and production unit are same, the activity is not continuous, the activity is separated.

Table 1. WBS of typical structural work

\begin{tabular}{|c|c|}
\hline Work & Detail work \\
\hline \multirow{6}{*}{ Formwork } & Inked string work \\
\hline & Disassembling wall form \\
\hline & Delivering/assembling wall form \\
\hline & Disassembling/Assembling Slab form \\
\hline & Disassembling of stair and core wall form \\
\hline & Delivering/assembling stair and core wall form \\
\hline \multirow{2}{*}{ Reinforcement work } & Delivering/assembling wall reinforcement \\
\hline & Delivering/assembling slab reinforcement \\
\hline \multirow{2}{*}{$\begin{array}{l}\text { Mechanical Electronic / } \\
\text { Communication work }\end{array}$} & Wall mechanical/electronic/communication work \\
\hline & Slab mechanical/electronic/communication work \\
\hline \multirow{2}{*}{ Concrete work } & Concrete pouring \\
\hline & Concrete curing and Slab form remaining \\
\hline Etc & Cleaning/Test/Finish \\
\hline
\end{tabular}

Fig. 1 shows a typical 12-day structural work schedule, which is developed from the WBS of Table 1.

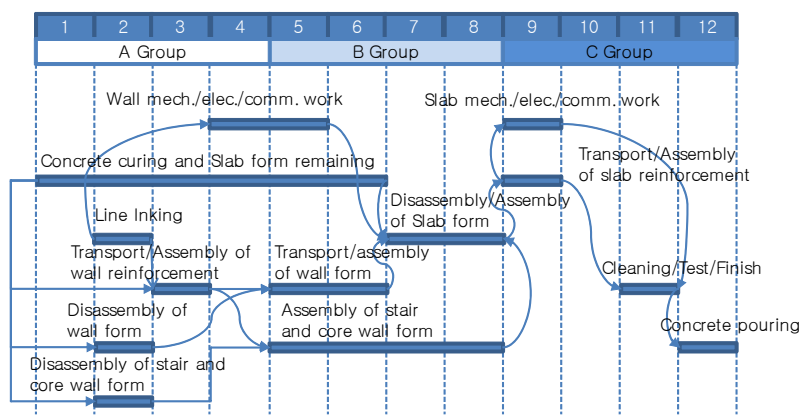

Figure 1. 12 days typical floor structural work schedule
The preliminary work is identified as inked string work. Inked string work begins after completing the below slab. Then, the below slab is followed by the inked string work, concrete curing, and slab form remaining period. However, inked string work can start one day later after concrete pouring, if the inked string work has a one day lag of slab form remaining period.

Wall and stairs/core wall form removal can start one day later after concrete pouring, with all three activities starting simultaneously.

After inked string work is finished, wall rebar delivery/assembling work starts. As written above, the relation of all the activities is set. However, mechanical work and electronic/communication work are similar to each other in method and starting and finishing times, and while there are differences between them, they are tied up to one activity.

\subsection{Activity duration}

After all the activities and the relation of each activity are defined, activity duration is estimated. Activity duration should be minimized and be considered according to productivity. The conditions of activity duration are as follows:

- All activity is only limited to physical and environmental conditions.

- The minimum duration is one day.

- There is no limitation of delivering workforce, while production unit, which is involved in the same work item, should be delivered repeatedly.

Based on above-mentioned conditions, activity duration is estimated in Table 2 .

Table 2. Detail activity duration

\begin{tabular}{c|c}
\hline Detail activity $(\text { Activity })^{*}$ & Duration \\
\hline Concrete curing and slab form remaining & 6days \\
\hline Inked string work & 1day \\
\hline Delivering/assembling wall reinforcement & 1day \\
\hline Disassembling wall form & 1day \\
\hline Disassembling stair and core wall form & 1day \\
\hline Wall mechanical/electronic/communication & 1day \\
\hline Delivering/assembling of wall form & 2days \\
\hline Disassembling/assembling Slab form & 2days \\
\hline Delivering/assembling stair and core wall form & 4days \\
\hline Delivering/assembling of slab reinforcement & 1(2)day(s) \\
\hline Slab mechanical/electronic/communication work & 1day \\
\hline Cleaning/test/finish concrete pouring & 1day \\
\hline
\end{tabular}

* Korea Concrete Institute (2003) was applied.

\subsection{Duration estimating standards}

Construction industries have their standard of duration estimation in making a construction schedule.

\section{(1) S company}

Table 3 shows the duration estimating standard of S company, which is a major construction company in Korea. 
Table 3. S company's duration estimating case

\begin{tabular}{|c|c|c|}
\hline Division & & Duration \\
\hline \multirow{3}{*}{$\begin{array}{c}\mathrm{T} 1 \\
\text { Preparatory } \\
\text { work }\end{array}$} & \multirow{2}{*}{ General area } & Good: 1month \\
\hline & & Usual : 1.5 month \\
\hline & Peculiar area & $\begin{array}{l}\text { Depending on the situation (islands, regulations } \\
\text { and restricted areas, squatters, etc.) }\end{array}$ \\
\hline \multirow{6}{*}{$\begin{array}{c}\text { T2 } \\
\text { Earthwork } \\
\text { and founda- } \\
\text { tion engi- } \\
\text { neering }\end{array}$} & \multirow{2}{*}{ t1 earthwork } & 1 underground floor : 1 \\
\hline & & 2 underground floors : 1.5 \\
\hline & \multirow[b]{2}{*}{$\mathrm{t} 2$ foundation } & Pile foundation : 0.5 \\
\hline & & $\begin{array}{c}\text { Down to } 3 \mathrm{~m}: 1 \\
\text { Down to } 5 \mathrm{~m}: 1.5\end{array}$ \\
\hline & \multirow{2}{*}{$\mathrm{t} 3$ mat } & More than $66,000 \mathrm{~m}^{2}$ of gross floor area : 1.5 \\
\hline & & Below than $66,000 \mathrm{~m}^{2}$ of gross floor area : 1 \\
\hline \multirow{4}{*}{$\begin{array}{c}\mathrm{T} 3 \\
\text { Structural } \\
\text { work }\end{array}$} & \multirow{2}{*}{$\begin{array}{l}\text { t4 understruc- } \\
\text { ture }\end{array}$} & 1 underground floor : 0.67 \\
\hline & & 2 underground floors : 1.33 \\
\hline & \multirow{2}{*}{$\begin{array}{l}\text { t5 superstruc- } \\
\text { ture }\end{array}$} & $\begin{array}{l}\text { Under } 15 \text { floors (n floors) } \\
: 2 \times 0.67+(\mathrm{n}-2) \times 0.45+0.3\end{array}$ \\
\hline & & $\begin{array}{c}\text { Above } 15 \text { floors ( } \mathrm{n} \text { floors) } \\
: 2 \mathrm{x} 0.67+13 \mathrm{x} 0.45+(\mathrm{n}-15) \times 0.5+0.3\end{array}$ \\
\hline \multirow{6}{*}{$\begin{array}{c}\text { T4 } \\
\text { Finish-work }\end{array}$} & \multirow{2}{*}{$\begin{array}{l}5 \text { floors } \\
\text { below }\end{array}$} & $\begin{array}{c}\text { More than } 11 \text { buildings : floor(understruct } \\
\text { ure+superstructure) } \times 1.2\end{array}$ \\
\hline & & $\begin{array}{l}\text { Less than } 10 \text { buildings : floor(understructu } \\
\text { re+superstructure) } \times 1.0\end{array}$ \\
\hline & \multirow{2}{*}{$\begin{array}{l}10 \text { floors } \\
\text { below }\end{array}$} & $\begin{array}{l}\text { More than } 66,000 \mathrm{~m}^{2} \text { of gross floor area : fl } \\
\text { oor(understructure+superstructure) } 0.6\end{array}$ \\
\hline & & $\begin{array}{l}\text { Less than } 66,000 \mathrm{~m}^{2} \text { of gross floor area : flo } \\
\text { or(understructure+superstructure) } 0.55\end{array}$ \\
\hline & \multirow{2}{*}{$\begin{array}{l}11 \text { floors } \\
\text { below }\end{array}$} & $\begin{array}{l}\text { More than } 66,000 \mathrm{~m}^{2} \text { of gross floor area : fl } \\
\text { oor(understructure+superstructure) } \mathrm{x} 0.65\end{array}$ \\
\hline & & $\begin{array}{l}\text { Less than } 66,000 \mathrm{~m}^{2} \text { of gross floor area : flo } \\
\text { or(understructure+superstructure)x0.6 }\end{array}$ \\
\hline
\end{tabular}

\section{(2) Korea Land and Housing Corporation (LH)}

According to the study of LH Research Institute (Korea Land and Housing Corporation, 2003), the estimating standard of the structural work is as follows:

Estimating Standard of LH

a) Structural work

- 15 floors below : 1st floor (29 days) + floor number X 12 days (above 2nd floor)

- 16 floors above : construction duration of 15th floor below + floor number $\mathrm{x} 13$ days (above 16th floor)

(Add if steel roof will take 9 days, and if concrete roof will take 13 days)

b) Finishing work

- 15 floors below : 127 days

- 16 floors above : 127 days +1 day/floor (above 16th floor)

\section{(3) L company}

Table 4. L company's estimating standard case

\begin{tabular}{l|l|c}
\hline & \multicolumn{1}{|c}{ Duration estimating standard } & Note \\
\hline \multirow{3}{*}{ Method 1 } & $\begin{array}{l}\text { Excavation and foundation work : separate calcula- } \\
\text { tions } \\
\text {-Structural work and finish work : } 1 \text { month/floor } \\
\text {-Other construction duration }: 3 \text { month }\end{array}$ & Experience \\
\hline Method 2 & $\cdot$ Construction duration : 1.5 month/floor & Experience \\
\hline
\end{tabular}

\section{(4) H company}

In the case of $\mathrm{H}$ company, construction duration is calculated by working day plus non-working day.

Table 5. Pure working days of structural work by floor

\begin{tabular}{c|c|c|c|c|c|c|c|c}
\hline Floor & $\begin{array}{c}\text { base- } \\
\text { ment }\end{array}$ & $\begin{array}{c}\text { under- } \\
\text { ground }\end{array}$ & 1 1st floor & $\begin{array}{c}2 \sim 4 t h \\
\text { floor }\end{array}$ & $\begin{array}{c}5 \sim 15 \text { th } \\
\text { floor }\end{array}$ & $\begin{array}{c}16 \text { th } \\
\text { floor }\end{array}$ & $\begin{array}{c}\text { Above } \\
17 \text { th } \\
\text { floor }\end{array}$ & $\mathrm{P} / \mathrm{H}$ \\
\hline $\begin{array}{l}\text { Number } \\
\text { of days }\end{array}$ & 10 & 22 & 25 & 12 & 10 & 13 & 10 & 24 \\
\hline
\end{tabular}

\subsection{Schedule influence factor in structural work}

In this chapter, schedule influence factors in structural work are analyzed through a case study.

Table 6. Cases of Apartment construction duration (Structural work)

\begin{tabular}{|c|c|c|c|c|c|c|}
\hline Corp. & Name of APT & $\begin{array}{l}\text { Hous } \\
\text { eholds }\end{array}$ & Floors & $\begin{array}{r}\text { Total } \\
\text { duration }\end{array}$ & $\begin{array}{c}\text { Duration } \\
\text { (day/floor) }\end{array}$ & Note \\
\hline \multirow{5}{*}{$\mathrm{L}$} & $\begin{array}{c}\text { Yeongtong-gu } \\
\text { APT }\end{array}$ & 1040 & $-3 / 20$ & 28 & 17.78 & $\begin{array}{l}\text { Flat- } \\
\text { type }\end{array}$ \\
\hline & $\begin{array}{l}\text { Sanghyeon-ri } \\
\text { (suji 2nd) }\end{array}$ & 992 & $-2 / 20$ & 29 & 12.96 & $\begin{array}{l}\text { Flat- } \\
\text { type }\end{array}$ \\
\hline & $\begin{array}{l}\text { Hwamyeong- } \\
\text { dong }\end{array}$ & 1950 & $-2 / 23 \sim 30$ & 36 & 11.32 & $\begin{array}{l}\text { Flat- } \\
\text { type }\end{array}$ \\
\hline & Hwagok-dong & 1164 & $-2 / 12 \sim 25$ & 33 & 11.97 & $\begin{array}{l}\text { Flat- } \\
\text { type }\end{array}$ \\
\hline & Bisan-dong & 965 & $-2 / 25$ & 34 & 13.52 & $\begin{array}{l}\text { Flat- } \\
\text { type }\end{array}$ \\
\hline \multirow{5}{*}{ S } & $\begin{array}{l}\text { Gileum-dong } \\
\text { Raemian }\end{array}$ & 1125 & $8 \sim 20$ & 32 & 13.1 & $\begin{array}{l}\text { Flat- } \\
\text { type }\end{array}$ \\
\hline & $\begin{array}{l}\text { Jongam-dong } \\
\text { Raemian }\end{array}$ & 1168 & $-3 / 16 \sim 20$ & 37 & 15.95 & $\begin{array}{l}\text { Flat- } \\
\text { type }\end{array}$ \\
\hline & $\begin{array}{l}\text { Dangsan-dong } \\
\text { Raemian 4th }\end{array}$ & 1391 & $-2 / 17 \sim 25$ & 37 & 15.5 & $\begin{array}{l}\text { Flat- } \\
\text { type }\end{array}$ \\
\hline & $\begin{array}{c}\text { Seocho } \\
\text { Raemian } \\
\text { (kukdong) }\end{array}$ & 1129 & $10 \sim 27$ & 38 & 11.08 & $\begin{array}{l}\text { Flat- } \\
\text { type }\end{array}$ \\
\hline & $\begin{array}{l}\text { Yongin-si } \\
\text { Gusung 1st }\end{array}$ & 1282 & $-2 / 11 \sim 20$ & 32 & 13.96 & $\begin{array}{l}\text { Flat- } \\
\text { type }\end{array}$ \\
\hline \multirow{3}{*}{$\mathrm{D}$} & Trump World & - & $-5 / 41$ & 39 & 14.5 & Tower-type \\
\hline & $\begin{array}{l}\text { Haeundae } \\
\text { Trump World }\end{array}$ & 564 & $-3 / 30 \sim 37$ & 45 & 11.8 & Tower-type \\
\hline & Sacheon Prugio & 998 & $-1 / 15$ & 26 & 12.3 & $\begin{array}{l}\text { Flat- } \\
\text { type }\end{array}$ \\
\hline \multirow{3}{*}{$\mathrm{H}$} & $\begin{array}{c}\text { Samseong-dong } \\
\text { I-Park }\end{array}$ & - & $-3 / 46$ & 38 & 11.6 & Tower-type \\
\hline & $\begin{array}{c}\text { Jangan-dong } \\
\text { Apartment }\end{array}$ & 2182 & $-2 / 12 \sim 28$ & 41 & 15.0 & $\begin{array}{l}\text { Flat- } \\
\text { type }\end{array}$ \\
\hline & $\begin{array}{l}\text { Haeundae } \\
\text { Hyperion }\end{array}$ & 266 & $-4 \sim 41$ & 35 & 8.6 & Tower-type \\
\hline
\end{tabular}

In the case of a common residential project, construction duration in superstructure structural work is about 10 13 days per floor, or approximately 12 days per floor.

The relationship between construction duration and the residential project scale are shown in Table 7. In Table 7, total construction duration is related to the number of households, while structural work duration is strongly related to the number of floors in the superstructure and in the understructure. However, the data did not explain that the construction cycle time per floor is mainly influenced by the structural work itself. 
Table 7. Relation between project scale and schedule

\begin{tabular}{|c|c|c|c|c|}
\hline & & Households & $\begin{array}{l}\text { Number of } \\
\text { superstruc- } \\
\text { ture floor }\end{array}$ & $\begin{array}{c}\text { Number of } \\
\text { understruc- } \\
\text { ture floor }\end{array}$ \\
\hline \multirow{3}{*}{ Duration } & $\begin{array}{l}\text { Pearson } \\
\text { correlation coef- } \\
\text { ficient }\end{array}$ & 0.143 & $0.498\left(^{*}\right)$ & 0.302 \\
\hline & p-value (both side) & 0.626 & 0.05 & 0.255 \\
\hline & $\mathrm{N}$ & 14 & 16 & 16 \\
\hline \multirow{3}{*}{$\begin{array}{l}\text { Structural } \\
\text { work dura- } \\
\text { tion }\end{array}$} & $\begin{array}{c}\text { Pearson } \\
\text { correlation coef- } \\
\text { ficient }\end{array}$ & -0.196 & $\left.0.8466^{(* *}\right)$ & $\left.0.8499^{* *}\right)$ \\
\hline & p-value (both side) & 0.503 & 0 & 0 \\
\hline & $\mathrm{N}$ & 14 & 16 & 16 \\
\hline \multirow{3}{*}{$\begin{array}{l}\text { Duration } \\
\text { by floor }\end{array}$} & $\begin{array}{c}\text { Pearson } \\
\text { correlation coef- } \\
\text { ficient }\end{array}$ & 0.382 & -0.405 & 0.102 \\
\hline & p-value (both side) & 0.178 & 0.12 & 0.707 \\
\hline & $\mathrm{N}$ & 14 & 16 & 16 \\
\hline
\end{tabular}

${ }^{* *}$ Correlation Coefficients notes level 0.01 (both).

* Correlation Coefficients notes level 0.05 (both).

\section{ANALYZING THE CONSTRUCTION METHOD FOR HIGH-RISE STRUCTURAL WORK}

\subsection{Outside wall form \\ (1) Gang form}

The basic elements of a gang form system include the sheathing (the surface that faces the concrete), studs, wales or walers, stiff backs or strongbacks, angle braces, ties, and safety equipment, including attached walkways and safety rails for workers to use during concrete placement and tie-offs for safety harnesses. Longer sections of gang forms require a spreader beam to easily distribute lifting forces from the crane.

Gang forms can be steel, aluminum, wood, plastic, or some combination of these materials. A wide selection is available from various form manufacturers. The system that you choose will be based on the number of reuses you hope to get, gang form weight, lateral pressures anticipated during concrete placement, cost, and the degree of architectural finish required. Gang forms typically get about 30-40 reuses. A 0.5 reuse per floor is economical over a 15 -floor residential project.

\section{(2) Guide-rail system (GRS)}

Form plate is the same as gang form, where the form below is fixed by a bolt, while a turn-buckle should be used for ensuring stability. When form is moved by a tower crane, the guide-rail system uses a rail for form moving, which makes it stable with the crane and wind load.

\section{(3) Auto-climbing system (ACS)}

The ACS operates as a self-climbing formwork system used for the construction of tall concrete structures, such as building core walls. The ACS provides fast cycle speed, easy operation, excellent construction quality, and the lowest in-place concrete cost in highrise building construction. Additionally, because ACS includes live load and wind load design, ACS is high in quality and is a safe construction method.

Table 8. Comparison Gang form, GRS and ACS

\begin{tabular}{|c|c|c|c|}
\hline Division & $\begin{array}{l}\text { Gang form } \\
\text { system }\end{array}$ & $\begin{array}{l}\text { Guide climbing } \\
\text { system }\end{array}$ & $\begin{array}{l}\text { Auto-climbing } \\
\text { system }\end{array}$ \\
\hline Cost & Cheapest & $\begin{array}{l}\text { Cheaper than Self } \\
\text { climbing }\end{array}$ & Expensive \\
\hline $\begin{array}{l}\text { Duration } \\
\text { (each floor) }\end{array}$ & $6 \sim 12$ days Cycle & 6 days Cycle & 5 days Cycle \\
\hline $\begin{array}{l}\text { Climbing } \\
\text { duration(each } \\
\text { floor) }\end{array}$ & 1 day & $\begin{array}{c}0.5 \text { day } \\
\text { (40ea Platform) }\end{array}$ & 1 hour \\
\hline Crane necessity & $\begin{array}{c}\text { Necessary } \\
\text { when climbing }\end{array}$ & $\begin{array}{c}\text { Necessary } \\
\text { when climbing }\end{array}$ & $\begin{array}{c}\text { Unnecessary } \\
\text { (minimize working } \\
\text { crane) }\end{array}$ \\
\hline $\begin{array}{l}\text { Pre-work, post- } \\
\text { work when } \\
\text { climbing }\end{array}$ & $\begin{array}{l}\text { Much more pre- } \\
\text { work, post-work }\end{array}$ & $\begin{array}{l}\text { Much more pre- } \\
\text { work, post-work }\end{array}$ & $\begin{array}{l}\text { Less pre-work, } \\
\text { post-work }\end{array}$ \\
\hline $\begin{array}{l}\text { Influence of } \\
\text { wind }\end{array}$ & $\begin{array}{l}\text { Absolute influ- } \\
\text { ence of wind } \\
\text { (getting worse to } \\
\text { be high altitude) }\end{array}$ & $\begin{array}{c}\text { Almost } \\
\text { never(design cri- } \\
\text { teria: wind speed } \\
45 \mathrm{~m} / \mathrm{sec})\end{array}$ & $\begin{array}{l}\text { none(design cri- } \\
\text { teria: wind speed } \\
\qquad 45 \mathrm{~m} / \mathrm{sec} \text { ) }\end{array}$ \\
\hline $\begin{array}{c}\text { Possibility of } \\
\text { safety-accident } \\
\text { when climbing }\end{array}$ & Very much & None & None \\
\hline $\begin{array}{l}\text { Possibility of } \\
\text { form modifica- } \\
\text { tion }\end{array}$ & Very much & Almost never & Almost never \\
\hline winter work & $\begin{array}{l}\text { Influence on } \\
\text { schedule }\end{array}$ & None & None \\
\hline $\begin{array}{l}\text { Selection Cri- } \\
\text { teria }\end{array}$ & $\begin{array}{l}\text { Building below } \\
25 \text { th floor (con- } \\
\text { sidering local } \\
\text { condition about } \\
\text { coast etc.) }\end{array}$ & 25th $\sim 35$ th floor & Above 35th \\
\hline $\begin{array}{l}\text { Type of pur- } \\
\text { chase }\end{array}$ & Buy & Almost lease & Almost lease \\
\hline
\end{tabular}

\subsection{System form}

System form is used for form works in order to improve the work efficiency of wall and slab form work and to shorten the construction period. There are many products for system form, but aluminum form (AL-Form) and al-wood form (AL-Wood Form) are frequently used in Korea.

They are produced at the factory according to the drawing, and can be easily assembled and dissembled at the site, resulting in shortening of form work duration in a typical floor.

\subsection{Other construction methods \\ (1) Stair construction method}

Stair work is also a process that requires time and workforce in 
structural work. To shorten this process, shop-fabricated stair steel form is used, or PC stair is prefabricated and installed in the site.

\section{(2) Use of CPB equipment}

CPB (Concrete Placing Boom) equipment is used for effective distribution of concrete at a high-rise structure or a large area.

\section{(3) Other methods}

To shorten the construction duration of structural work, work is conducted by separating horizontal spaces. To simplify the structural work, the location of the wall is adjusted, or PC is installed partially.

\section{CASE STUDY}

\subsection{Case overview}

\section{(1) $\mathrm{H}$ project}

In terms of construction scale, the case involves two (2) buildings in a reinforced concrete structure with 41 42 stories above ground and 4 below. Its total gross floor area is $85,476.75 \mathrm{~m}^{2}$. The ACS with fast lifting speed is used on the external wall of the structure of form, and the standardized gang form (aluminum form) is used on the internal part in order to raise the efficiency of the works.

To endure the compressive strength of a high-rise building, highstrength concrete with compressive strength of over $270 \mathrm{~kg} / \mathrm{cm}^{2}$ was used (ACI Committee 209, 1992). For the $4 \sim 2$ stories below the ground and the 39 stories above the ground, concrete with compressive strength of over $400 \mathrm{~kg} / \mathrm{cm}^{2}$ was used in an earthquakeresistant design. For the stairs, PC stairs are lifted with a tower crane and are then assembled. Only the stair landing is executed along with reinforced concrete work, resulting in the shortening of the number of process days and securing of the quality.

The tower crane was arranged so that the Tip Load would be maximized in consideration of the lifting of the rebar and the gang form, and by reviewing whether or not there is no interference with neighboring high-rise buildings that may delay construction. One unit of a 12-ton T/C per building was planned in consideration of the gang form lifting the work and rebar work period, but the plan was changed to 1 unit of T/C 20 ton due to ACS.

\section{(2) T project}

In terms of construction scale, the case focuses on the building in reinforced concrete structure with 30 37 stories above ground and 3 stories below ground. Its total gross floor area is $125,513.59 \mathrm{~m}^{2}$ and the height is $119.6 \mathrm{~m}$. For the form, the GRS with a stable T/C lifting was used on the external wall of the structure, while the gang form and the aluminum form were used for the external inner wall and the inside form that was the same as in the $\mathrm{H}$ project. The box form was used for the CORE part of the elevator, simplifying and dissembling them than the existing form. At the 4th floor, concrete was poured over the pillar, the 1st and 2nd pillar (a total of 3 times), with an earthquake-resistant design. For stair work, it is shopfabricated and is only assembled in the site.

\subsection{Comparison and analysis of process schedule of $\mathrm{T}$ project and $\mathrm{H}$ project}

The number of process days for the two (2) sites were compared by applying the system classified in Table 9 to the number of working days and work operation system.
Table 9. Structural work type comparison between $\mathrm{H}$ and $\mathrm{T}$ site

\begin{tabular}{|c|c|c|c|c|}
\hline & & $\mathrm{H}$ site & T site & Note \\
\hline \multirow{3}{*}{ Form work } & $\begin{array}{c}\text { Outer } \\
\text { wall }\end{array}$ & $\begin{array}{c}\text { ACS } \\
\text { (Self climbing) }\end{array}$ & $\begin{array}{l}\text { GRS(Tower } \\
\text { Crane) }\end{array}$ & $\begin{array}{c}\text { ACS } \\
\text { (advantageous } \\
\text { schedule) }\end{array}$ \\
\hline & $\begin{array}{c}\text { Inside } \\
\text { wall }\end{array}$ & $\begin{array}{l}\text { Aluminum } \\
\text { system form }\end{array}$ & $\begin{array}{c}\text { Al-wood form } \\
\text { box form(core) }\end{array}$ & Similar \\
\hline & Stairs & PC stairs & $\begin{array}{l}\text { Al-wood, steel } \\
\text { prefab form }\end{array}$ & $\begin{array}{c}\text { Similar (PC stars } \\
\text { a little advanta- } \\
\text { geous) }\end{array}$ \\
\hline \multirow{2}{*}{$\begin{array}{l}\text { Reinforc- } \\
\text { ing rod } \\
\text { assembly }\end{array}$} & Walls & $\begin{array}{l}\text { pre-cutting rein- } \\
\text { forcing rod }\end{array}$ & $\begin{array}{l}\text { pre-cutting rein- } \\
\text { forcing rod }\end{array}$ & same \\
\hline & Slabs & $\begin{array}{l}\text { pre-cutting rein- } \\
\text { forcing rod }\end{array}$ & $\begin{array}{l}\text { pre-cutting rein- } \\
\text { forcing rod }\end{array}$ & same \\
\hline \multicolumn{2}{|c|}{ Concrete pouring } & $\mathrm{CPB}$ & $\mathrm{CPB}$ & same \\
\hline
\end{tabular}

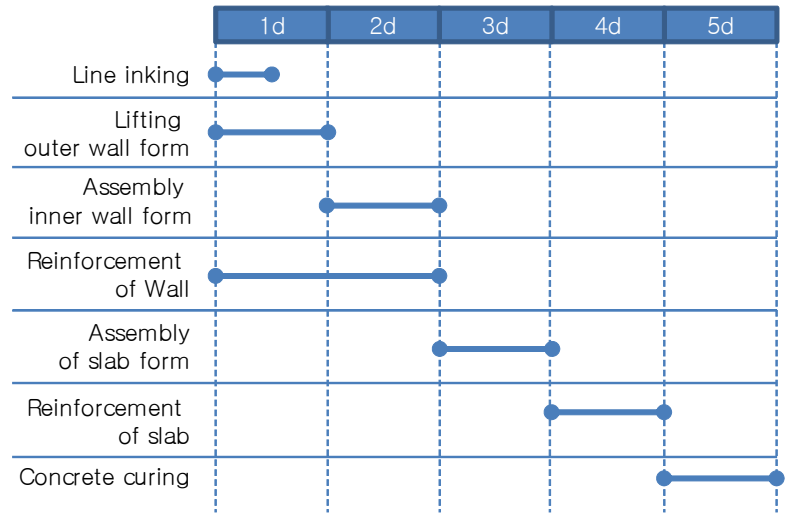

Figure 2. Structural work 5-day cycle

\subsubsection{Analysis of the floor cycle time of the T project}

(1) Curing/inked string work

Since the restriction on the form remaining period of six (6) days was removed from the high-strength concrete of over $270 \mathrm{~kg} / \mathrm{cm}^{2}$ and two (2) sets of slab form, inked string work can be conducted immediately after concrete pouring. Inked string work was performed for 0.5 days, shortening the two (2) processes by 1.5 days compared to the basic process.

(2) Delivery and assembling of wall rebar arrangement, delivery and assembling of wall form and wall electricity/communication/ equipment

The basic process becomes a 4-day process: adding wall rebar assembling for one (1) day, wall form for two (2) days, and wall electricity/communication/equipment process with a 1-day delay. In the $\mathrm{T}$ project, wall rebar assembling takes two (2) days, including the simultaneous process with the preparation/dissembling/ lifting of the external wall form preparation, as shown in Fig. 2. Since electricity / communication/equipment processes are also simultaneous processes, these processes combined to entail 3.5 days, resulting in shortening the process to 0.5 day.

(3) Slab form removal/assembling, delivery

The basic process becomes a 4-day process: adding slab form/ dissembling/assembling for two (2) days, and slab rebar delivery/ assembly for two (2) days. In the T project, shop-fabricated/field- 
assembled ready-made form was used for the stair/core form on the site, so that it is not related to construction. By increasing workforce and pre-assembled rebar and closing the slab electricity/ communication/equipment at the same time, the period of slab form work was shortened to 1.5 days and slab rebar arrangement to one (1) day.

Since cleaning inspection/finishing was not included in the calculation of the number of main process days, but included the slab rebar arrangement process, the main process was shortened by one (1) day. Fig. 2 shows that 0.5 day was shortened from the main process by performing inked string work and wall rebar work at the same time. As a result, the process plan lasting a total of seven (7) days was obtained from the T project by combining one (1) day of concrete pouring.

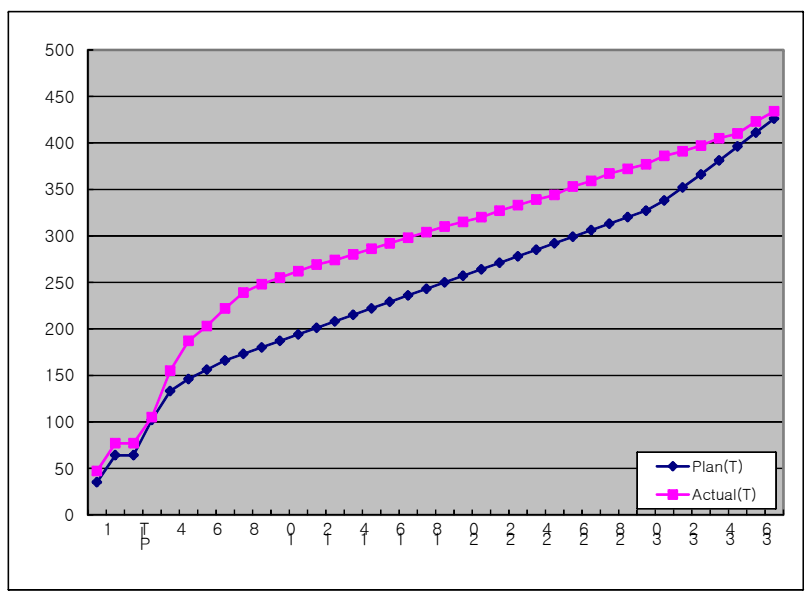

Figure 3. Schedule performance of case $\mathrm{T}$

\subsubsection{Analysis of the floor cycle time of the $H$ project}

In the $\mathrm{H}$ project, the process was shortened to five (5) days by using the shortening construction method of the $\mathrm{H}$ project from the T project. Since the shortening factor of the $\mathrm{H}$ project overlapped with the analysis of the number of shortened days in the $\mathrm{T}$ plan process, the $\mathrm{H}$ project was analyzed by focusing on the shortening factor in reference to Fig. 2 based on the T project.

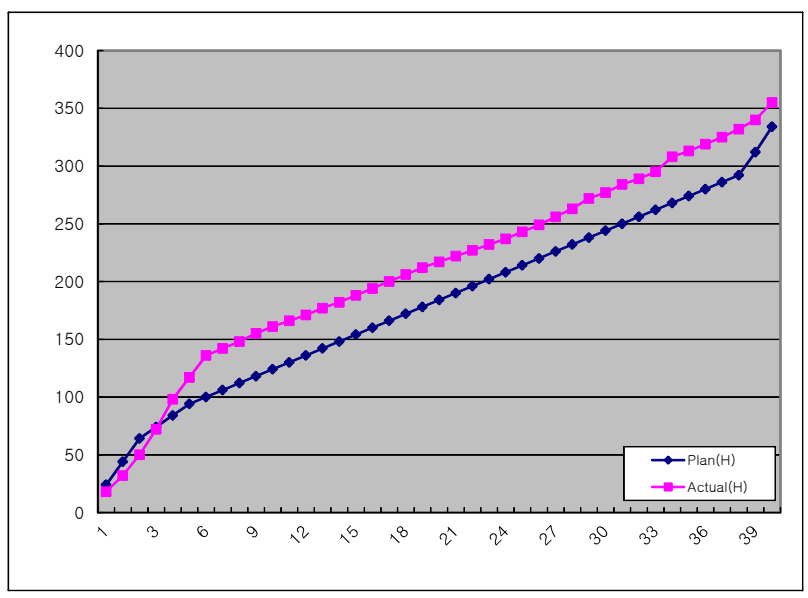

Figure 4. Schedule performance of case $\mathrm{H}$

(1) Lifting of external wall/internal wall form, wall rebar arrangement ACS was used for the external wall form in the $\mathrm{H}$ project so that it could be started simultaneously with inked string work without preparation for lifting due to self-lifting rather than crane lifting of GRS in the T project, resulting in shortening the process for 0.5 days. Furthermore, lifting speed was planned 0.5 days faster than the GRS (T project) due to the ACS feature. Wall rebar work was conducted along with external form work so that wall form work could start immediately, shortening overall wall work for 1.5 days.

\section{(2) Slab form}

The process was reduced by using the ready-made form for stair work in the T project, but 0.5 days were shortened more in the $\mathrm{H}$ project by using the PC stair construction method. Since electricity/ equipment is conducted simultaneously with form, it was found not to affect the total number of days it took to complete the process.

Fig. 5.6 shows the plan process that was analyzed by correcting the number of non-working days in Table 10 to process the work in the $\mathrm{H}$ project and in the T project, which is, 5 days and 7 days of processing day per floor, respectively.

Table 10. Non-working days planning

\begin{tabular}{|c|c|c|c|c|c|c|c|c|c|c|c|c|c|}
\hline year & Jan & Feb & Mar & Apr & May & Jun & Jul & Aug & Sep & Oct & Nov & Dec & Sum \\
\hline 2003 & 1 & 2 & 4 & 10 & 7 & 5 & 16 & 11 & 5 & 0 & 6 & 1 & 68 \\
\hline 2002 & 3 & 1 & 4 & 5 & 4 & 3 & 9 & 11 & 3 & 5 & 1 & 4 & 53 \\
\hline 2001 & 4 & 2 & 0 & 3 & 4 & 5 & 7 & 6 & 4 & 3 & 1 & 1 & 40 \\
\hline 2000 & 1 & 0 & 5 & 3 & 5 & 4 & 6 & 8 & 5 & 2 & 3 & 0 & 42 \\
\hline 1999 & 2 & 2 & 6 & 2 & 7 & 7 & 5 & 10 & 8 & 4 & 0 & 0 & 53 \\
\hline 1998 & 3 & 6 & 4 & 8 & 7 & 10 & 8 & 11 & 2 & 4 & 2 & 0 & 65 \\
\hline 1997 & 1 & 2 & 3 & 5 & 6 & 6 & 8 & 8 & 3 & 0 & 5 & 2 & 49 \\
\hline Avrage & 2.14 & 2.14 & 3.71 & 5.14 & 5.71 & 5.71 & 8.43 & 9.29 & 4.29 & 2.57 & 2.57 & 1.14 & 52.86 \\
\hline
\end{tabular}

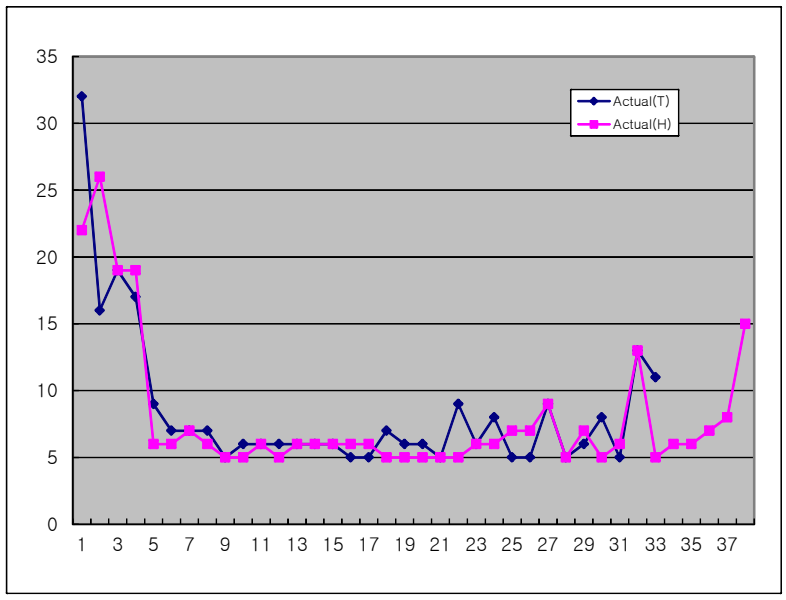

Figure 5. Schedule performance of $\mathrm{H}$ site and $\mathrm{T}$ site

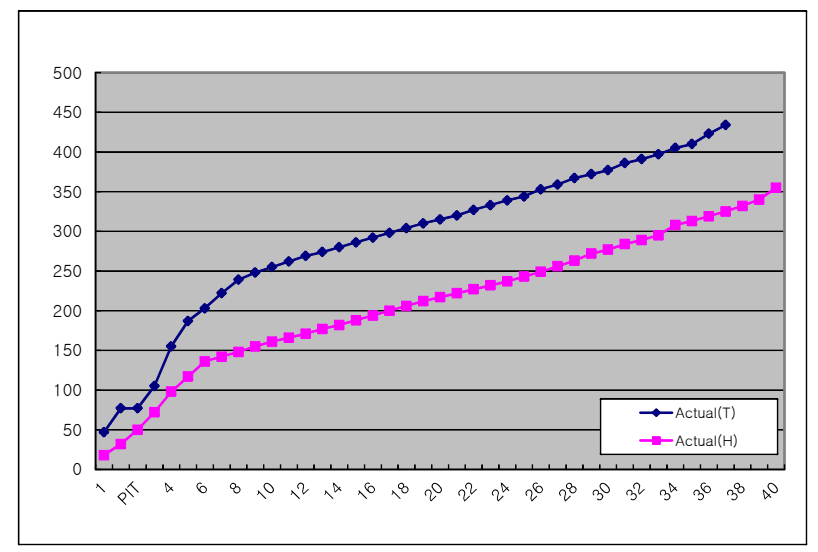

Figure 6. Cumulative schedule performance of $\mathrm{H}$ site and $\mathrm{T}$ site 
In Fig. 5 in which the process plans were compared, it was found out that it took nine (9) days from the 11th floor to the 29th floor in the T project, and six (6) days in the $\mathrm{H}$ project. Based on the difference in speed at the $\mathrm{H}$ project and the T project in Fig. 6, the difference in the number of work days of the overall work duration started with 22 days at the 10th floor, and began to increase and reached 136 days at the 49th floor. From this result, it is known that work progress speed becomes faster in the $\mathrm{H}$ project than in the $\mathrm{T}$ project over time.

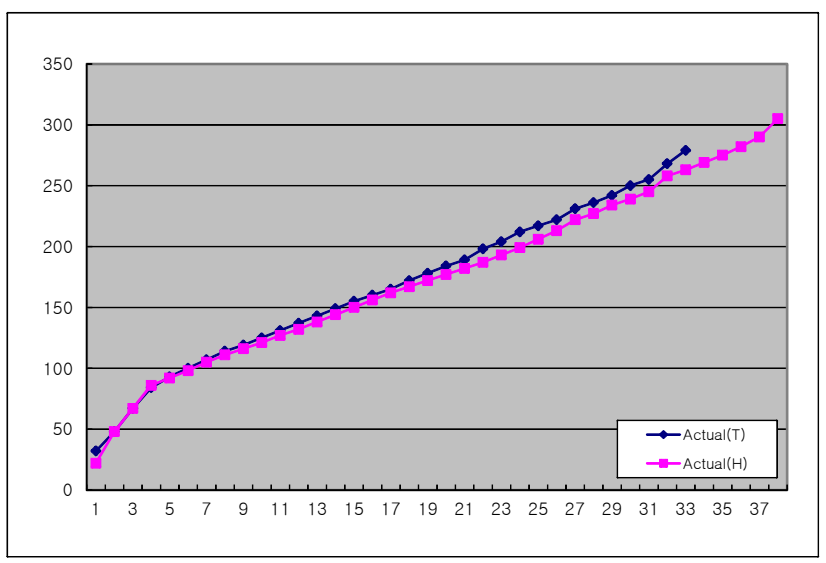

Figure 7. Schedule performance comparison(typical floor)

\subsection{Comparison of the number of process days among actual ASC, GRS, and gang form}

While they were compared with the process plans of each project above, the H project (ACS), the T project (GRS), and the P project (gang form) were compared, as shown in Fig. 8 and Fig. 9, in order to analyze the factors in work duration change due to the form factor in actual work.

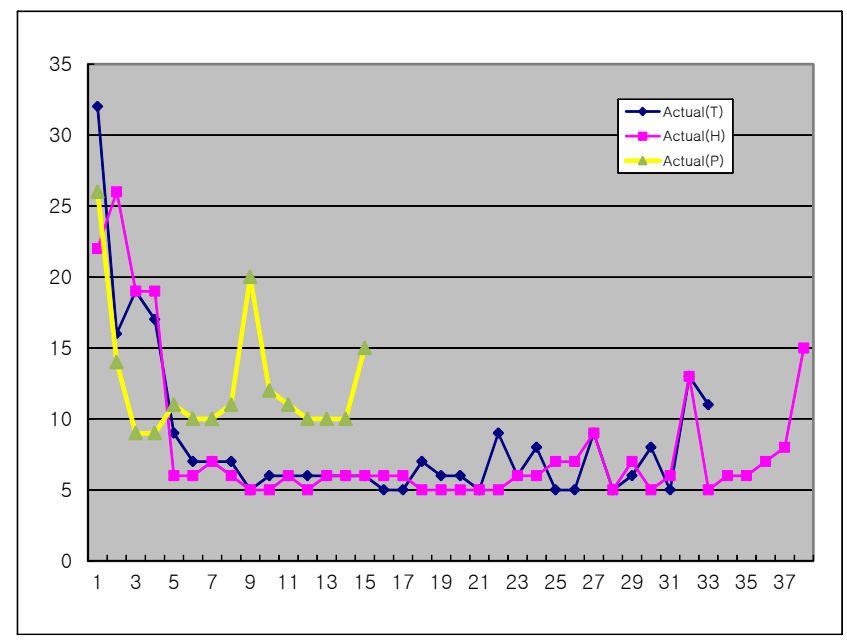

Figure 8. Duration comparison of $\mathrm{H}, \mathrm{T}$ and $\mathrm{P}$ site

Fig. 8 shows that work was faster in the $\mathrm{H}$ project due to form setting on the 3rd and 4th floor and initial lifting work. However, when comparing the number of each process day at the typical floor (5th floor $\sim 38$ th floor) in the H project and the T project, as shown in Fig. 9, the $\mathrm{H}$ project records 6.6 days per floor, while the $\mathrm{T}$ project records 7.2 days per floor, meaning that the $\mathrm{H}$ project was proceeding faster by 0.6 days per floor. While proficiency does not affect the schedule since ACS is lifted due to the control of the overall mechanical system after setting is finished at the 3rd and 4th floors, GRS is lifted with a crane so that proficiency in lifting preparation will affect the process. It is analyzed that a difference might occur up to the 7 th floor in the $\mathrm{H}$ project and in the $\mathrm{T}$ project, but there was almost no difference found in construction duration after that floor.

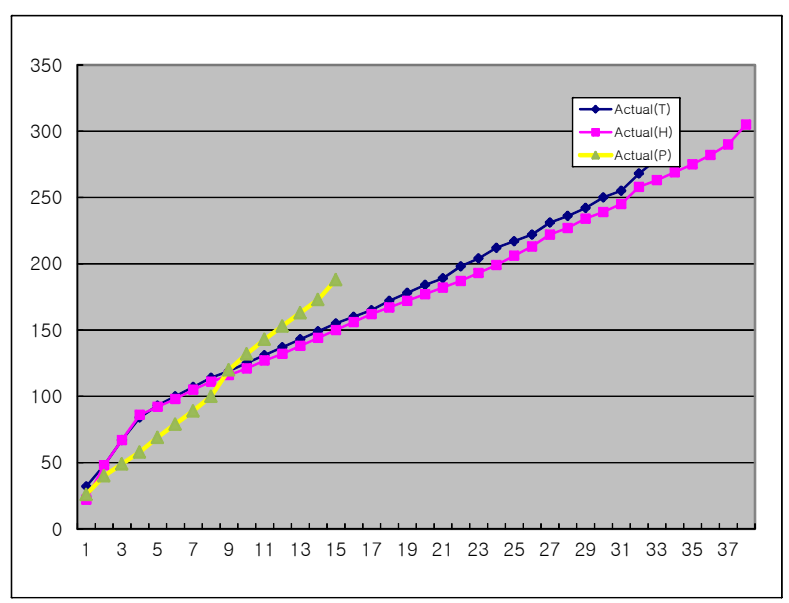

Figure 9. Cumulative duration comparison

The $\mathrm{P}$ project records an average of 10.8 days per floor, and slope is constant. Fig. 9 shows that it intersects with that of the $\mathrm{H}$ project at the 15th floor, and with that of the T project at the 21st floor. As a result, the H project (ACS) was found to be more effective than gang form at stories above the 15th floor, and in the T project (GRS) at stories above the 21 st floor.

\subsection{Simulation of working days in high-rise structural work}

Simulation can be used to estimate the duration of structural work in future projects. We used the Monte-Carlo simulation method to estimate structural working duration in this paper. The total duration of structural work can be calculated with the following formula.

Time $($ Structural work $)=$ Time $($ Form setting $)+$ Time $($ Typical floor) + Time (Penthouse)

The distribution of structural work duration of a typical floor and lower floors are as follows:

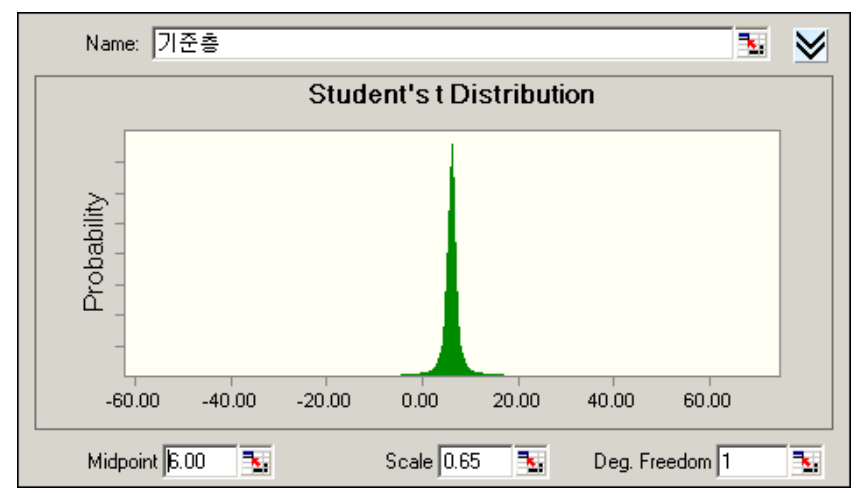

Figure 10. Distribution of 1 floor structural work cycle 


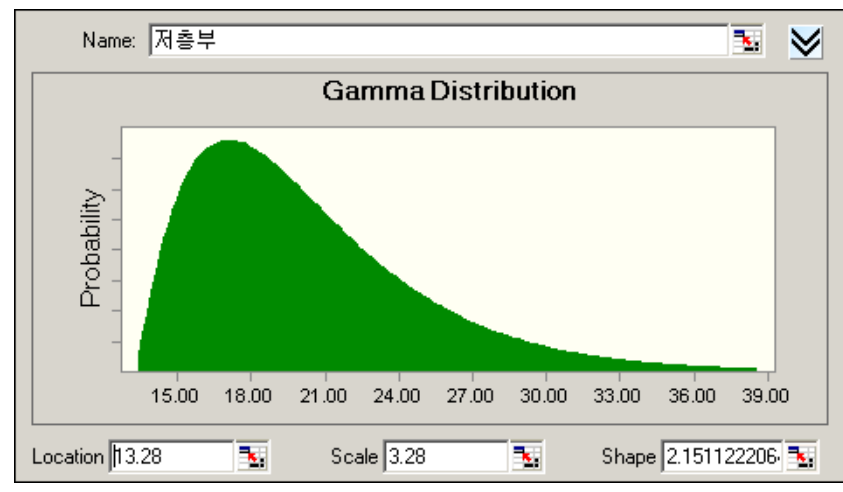

Figure 11. Distribution of system form setting duration

With this distribution, the result of the Monte-Carlo simulation is as follows on Fig. 12 and Table 11. With this result, we can find that the error rate of the duration estimation is below 5\%, and this method can be used to planning a similar project.

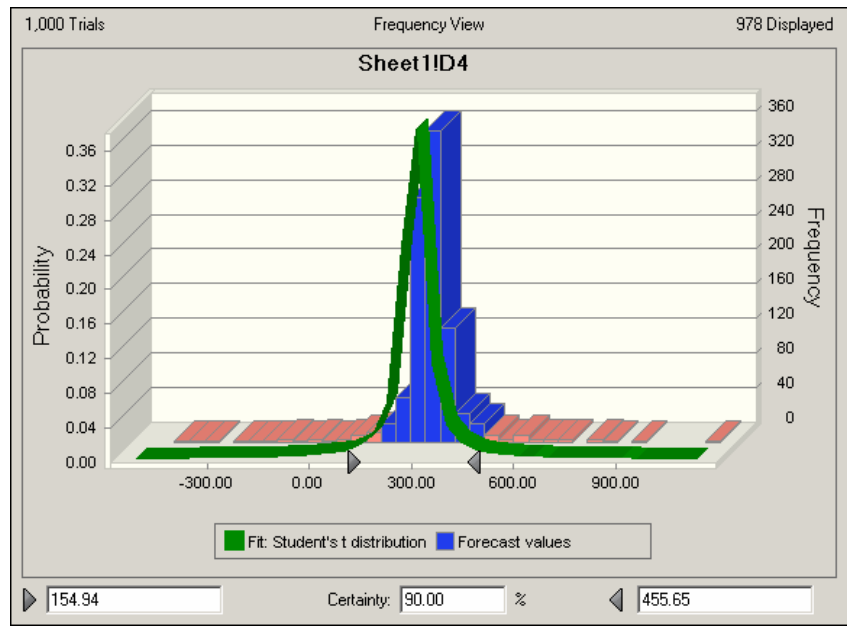

Figure 12. Result of duration simulation of 39th floor case

Table 11. Analysis of simulation result

\begin{tabular}{c|c|c}
\hline & Result(days) & Note \\
\hline $\begin{array}{c}\text { Initial planning } \\
\text { schedule }\end{array}$ & 290 & $\begin{array}{c}\text { Form setting }: 20 \text { days }^{*} 4 \text { floors } \\
\text { Typical floor }: 6 \text { days } * 35 f l o o r s\end{array}$ \\
\hline Actual schedule & 305 & error rate $4.91 \%$ \\
\hline Simulation & 297.38 (average) & error rate $2.6 \%$ \\
\hline
\end{tabular}

\section{CONCLUSION}

Land price and lifestyle have created high-rise residential projects with increased construction duration and difficulty. In a highrise residential project, framework is the most time-consuming, therefore, a construction company must focus on reducing construction duration. Framework consists of inked string work, delivery and assembling of rebar arrangement, form removal and assembling, and concrete curing. Among those composite works in framework, this research was performed by considering two aspects: shortening construction duration and feasibility in formwork. Gang form is effectively used in buildings with less than 15 floors. However, in buildings with more than 15 floors, it is not suitable due to wind and stability. This research focused on ACS and GRS of a residential project with over 15 floors.

This study suggested Equation 3) based on data on effectiveness. According to Equation 3), the longer the construction duration, the lesser is the cost of ACS. It means that in high-rise structures, ACS is more effective than GRS.

\section{REFERENCES}

ACI Committee 209, (1992) Prediction of creep, shrinkage, and temperature effects in concrete structures

Bang J., Lee B., Cho K,. Kang D,. Kim S., (2001) "A Study on the Efficient Project Control for the Time Shortening in Apartment Building: Focused on the Flat-DW Structure System", Korea Land and Housing Corporation

Han, C., Bang, J., (2004) "Development of an Effective Time Scheduling Mechanism of the Structural Framework for the High-rise Apartment Housing : Focusing on One Cycle Time Scheduling Mechanism of Typical Floor." Korea Journal of Construction Engineering and Management, 5(4):87-96

Ji, S, Hyun C,. (2012) "Development of Schedule Estimating Method for Structure Frame Works based on Space Breakdown Structure and Productivity Analysis in Public Multi-Housing Projects." Journal of Architectural Institute of Korea, v.28, n. 02, pp. 95-104

Korea Concrete Institute, (2003) Standard Concrete Specification

Korea Land and Housing Corporation, (2003) Construction Standard Specification

Sim, M., Kwon, O., Kim, K. (2009) Architectural Schedule management, Kimundang, Seoul.

(Received June 29, 2012/Accepted July 9, 2012) 